\title{
The Dividend Pricing Model: New Evidence from the Korean Housing Market
}

\author{
Min Hwang • John M. Quigley • Jae-young Son
}

(C) Springer Science + Business Media, Inc. 2006

\begin{abstract}
It is generally conceded that dividend pricing models are poor predictors of asset prices. This finding is sometimes attributed to excess volatility or to a dividend process manipulated by firm managers. In this paper, we present rather powerful panel tests of the dividend pricing relation using a unique data set in which dividends are set by market forces independent of managers' preferences. We rely on observations on the market for condominium dwellings in Korea-perhaps the only market in which information on dividends and prices is publicly and continuously available to consumers and investors. We extend the "dividend-price ratio model" to panels of housing returns and rents differentiated by type and location. We find broad support for the dividend pricing model during periods both before and after the Asian Financial Crisis of 1997-1998, suggesting that the market for housing assets in Korea has been remarkably efficient.
\end{abstract}

Keywords Housing price $\cdot$ Rent $\cdot$ Present value $\cdot$ Asset prices

\section{Introduction}

There is now considerable research devoted to testing the implications of the dividend pricing model. A general finding is that present value models are not good

Previous versions of this paper were presented at the Hong Kong-Singapore International Real Estate Research Symposium, August 2004, Hong Kong and the meeting of the Hong Kong Economic Association, January 2005. We are grateful for the comments of Ashok Bardhan, Yuming $\mathrm{Fu}$, Chinmoy Ghosh, Lok Sang Ho, Charles Ka Yui Leung, Sau Kim Lum and Seow Eng Ong. Son's research was supported by the Konkuk University and Hwang's research was supported by the National University of Singapore.

M. Hwang $(\bowtie)$

National University of Singapore, Singapore, e-mail: rsthm@nus.edu.sg

J. M. Quigley

Univeristy of California, Berkeley, CA, USA

e-mail: quigley@econ.berkeley.edu

J. Son

Konkuk University, Seoul, South Korea

e-mail: jyson@konkuk.ac.kr 
predictors of the actual prices of shares traded in financial markets. This lack of fit is interpreted as excess volatility in prices, or alternatively as a failure of the maintained hypothesis that the discount rate for dividends is constant. Considerable discretion in the payout of dividends is vested in the managers of firms who may follow rules of thumb in awarding dividends. Managers may also be reluctant to increase dividends unless they expect that the payout can be maintained subsequently. ${ }^{1}$ The failure of the present value model can thus be attributed to the dividend process followed by firm managers who exercise discretion over timing and payout forms, and whose behavior differs from the mechanical process assumed in econometric models.

In this paper, we present rather powerful tests of the dividend pricing relation using a unique body of data on assets for which dividends are set by market forces independent of managers' preferences. We rely, not upon observations on shares traded on organized financial markets, but on observations taken from the market for condominium dwellings in Korea-perhaps the only market in which information on dividends for individual assets is publicly and continuously available to consumers and investors who trade them over short-term intervals. We test the present value model using large panels of observations on asset price movements and dividends.

Section 2 describes the Korean housing market and the unique institutions that provide precise data which support our test of present value models. Sections 3 and 4 outline the nature of our tests and report the results. We present three kinds of evidence. First, we describe the cross sectional characteristics of returns to investment based on panels of virtually identical housing units, differing by type and location, noting the importance of lags and analyzing simple investment strategies. Second, we present tests for the stationarity of dividend price ratios in each of our panels of dwellings. Following Craine (1993) and generalizing, we conduct a series of unit root tests based upon panels of price-rent ratios, differentiated by type of housing, investigating the stationarity of dividend price ratios. With the exception of the period surrounding the Asian Financial Crisis of 1998, we find that the time series are quite consistent with stationary processes. The stationarity of dividend price ratios supports our third analysis, an extension of the "dividend-price ratio model," originally proposed by Campbell and Shiller (1988), to panels of housing returns and rents, differentiated by size and location. In contrast with much of the existing literature, we find broad support for the dividend pricing model in this more general framework.

Taken together, these results provide broad support for the dividend pricing model as a predictor of asset prices and thus for the efficiency of the Korean housing market. Section 5 is a brief conclusion.

\section{The Korean Housing Market}

\section{Apartments}

We test the present value relationship using micro data on the Korean housing market during the period from 1990-2002. We divide the time period into two

\footnotetext{
${ }^{1}$ In addition, ordinary dividends might not represent true cash flows; share repurchases and takeover distributions are also relevant cash flows for the pricing of shares. See Kleidon (1986), Marsh and Merton (1986) and Ackert and Smith (1993).
}

Springer 
parts: 1990:Q1 through 1997:Q3, the period before the Asian Financial Crisis; and 1999:Q1 through 2002:Q3, the period after the end of the crisis. We rely upon the data on housing units which Koreans call "apartments" in the capital region surrounding Seoul. ${ }^{2}$ Apartments are high-density attached dwellings in high-rise buildings, typically built in large complexes of multi-story buildings. The size of an apartment complex varies widely, but it commonly contains three or more types of dwellings, differentiated by size, and consists of several hundred units. Apartment construction in Korea began in earnest in the early 1970s, and soon thereafter became the dominant housing development pattern in the country. Apartments accounted for 81 percent of all new dwellings constructed in Korea between 1995 and 2000, and they represented almost half of the housing stock in the country in 2000 .

Easy to mass-produce, the apartment has been the central instrument in Korean housing policies aimed at providing subsidized apartments to middle class consumers. Public sector monopolies such as the Korean Land Corporation and the Korea National Housing Corporation developed and provided inexpensive land to homebuilders, who in turn were required (until 1998) to sell apartments at regulated prices. ${ }^{3}$ Under these price regulations, the developers' objective was to cram as many units as possible on a given site, using standard materials and approved designs. As a result, Korean apartments in the same size classes are much more homogeneous than are dwellings in most other countries.

Most apartments are built for sale, and each unit is typically owned by an individual. ${ }^{4}$ The rental market for apartments is active and lively, but few apartment complexes have been built to provide permanent rental accommodation. Rather, the rental housing supply consists of units which individual owners choose to rent, customarily on a fixed two-year basis. An owner-occupied apartment can be turned into a rental unit, and vice versa, anytime without cost. Apartment complexes built specifically to provide permanent rental accommodations do not exist in Korea except for a small number of apartments for families with very low incomes.

This high degree of homogeneity and the fused rental and owner-occupied markets make the Korean apartment housing market unusual in several respects. First, since floor plans, building materials, and amenities are standardized, market participants have very good ideas of what to expect about any specific dwelling for a given location, size, and vintage. This homogeneity means that apartments can be easily traded and rented, not only for residential but also for investment purposes. In fact, persistent price inflation has made apartments important and actively-traded assets in the wealth portfolios of middle-class households. To many owners the investmentasset aspect of apartments may be more important than the durable-good consumption aspect. If there are inefficiencies in the market, they do not arise from

\footnotetext{
${ }^{2}$ The region consists of the city of Seoul, the city of Inchon, and Kyunggi Province. Seoul is the capital of the country, Inchon is a port and industrial city, and Kyunggi Province envelopes both cities. See Fig. 1.

${ }^{3}$ Thus, the housing policy was ultimately funded by home-buyers, and did not rely on an explicit budgetary allocation from the central government. This strategy had major a weakness: the neglect of low-income families who could not buy a home even at regulated prices. For detailed discussion of Korean housing policies, see Son et al. (2003).

${ }^{4}$ In this sense, apartments in Korea are similar to condominiums in the U.S.
} 


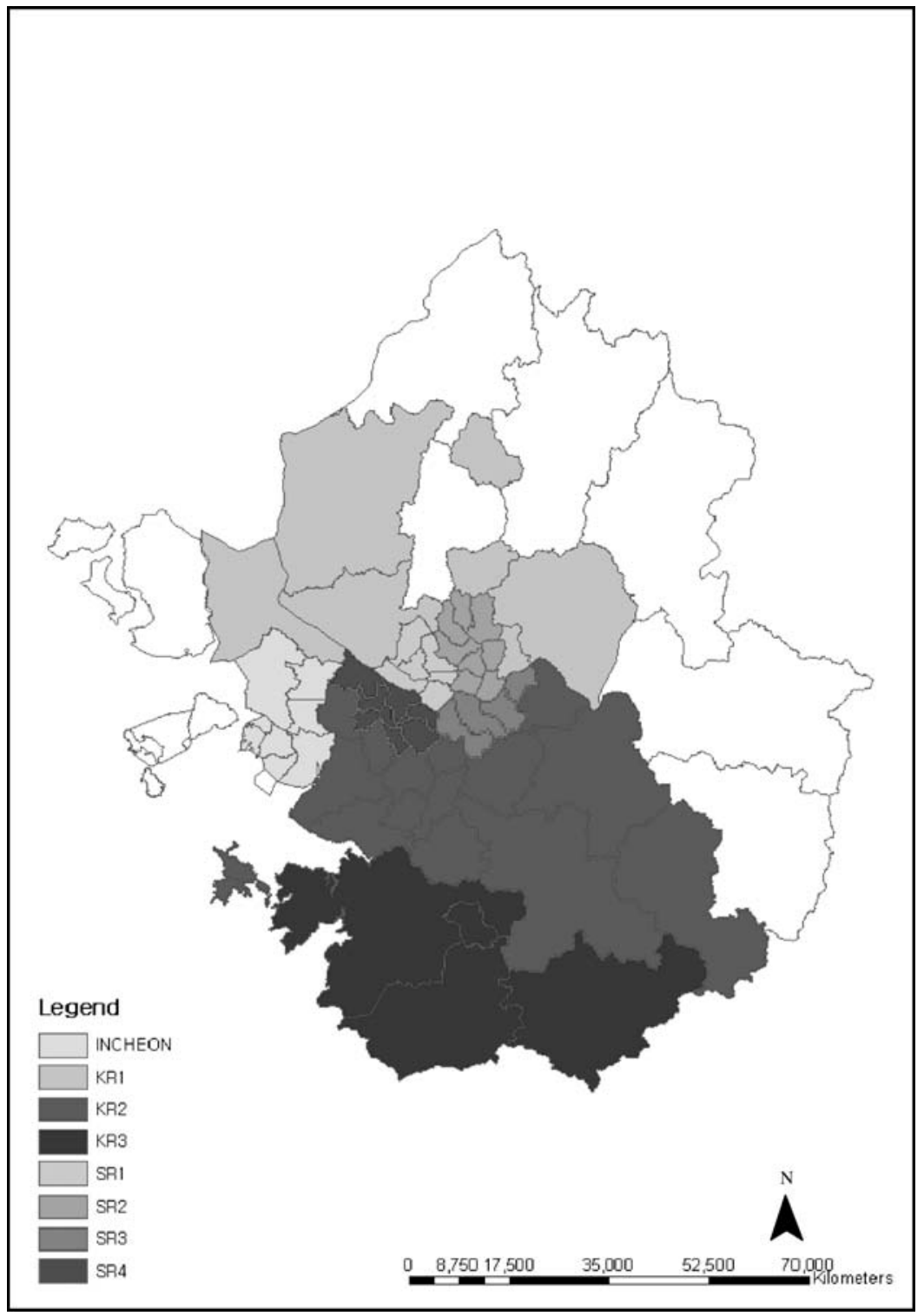

Fig. 1 Geographical submarkets in the Seoul metropolitan region

thin markets; the market is deep and active compared with housing markets in most other countries.

Secondly, since apartments are actively traded and there are hundreds of similarvirtually identical-apartments in any neighborhood-reference prices and rents are easily found, and this information flows fast and freely. It is quite routine to find neighborhood brokers who can provide daily movements of prices, both rental and sale prices. Several companies gather such information from local brokers and Springer 
regularly publish current prices in print and online. ${ }^{5}$ These surveys are considered to be an accurate reflection of the market, and they heavily affect the buy-, sell-, and rent-behavior of market participants. For researchers, this information provides a continuous series of prices and rents on well-specified assets at the micro-level, a rarity in other countries.

Third, apartment prices are quoted as a pair-rental prices (discussed below) and sale prices-since the rental and owner-occupied markets are perfectly fused. Housing researchers in other countries have difficulties in constructing rent and sale price data which control for the myriad differences between rental and owner-occupied dwellings (Meese and Wallace, 1994). With data on Korean apartments, one can match the rent to the selling price of an identical unit, and indices of the rent and the sale price of apartments can be constructed from the same set of dwellings.

Finally, transactions costs are relatively low compared with other countries. Brokerage fees are normally between one half and one percent, and the homogeneity of apartments keeps search costs low. Only tax burdens are high; the taxes payable at the time of purchase are effectively between three and four percent of the price.

In summary, many attributes which are thought to be the sources of inefficiency in local real estate markets are absent in the Korean apartment market. And many of the data problems which preclude testing of the dividend pricing model in financial markets are also absent. Indeed, this may be one of few real property markets where efficiency holds and one of the few asset markets in which the link between dividends and prices can be tested directly.

\section{Chonsei Rental Contracts}

All segments of the Korean real estate rental market, including residential, commercial, and even industrial sectors, involve rental contracts called Chonsei. ${ }^{6}$ Under a Chonsei rental contract, the tenant makes a single large deposit in lieu of monthly rent payments, and the interest income that accrues to the landlord constitutes the rent. At the end of the rental term, the deposit is returned in full to the tenant. As an institution, the Chonsei rental contract is ubiquitous in the midand upper-level residential rental market. According to the 2000 census, 43 percent of all households were living in rental dwellings, and two-thirds of them were on Chonsei contracts. The rental term of a Chonsei contract is legally set at two years.

The Chonsei system combines two separate transactions in a single contract. The first is a loan made by the tenant to the landlord, and the second is a lease by which the landlord grants use of the residence to the tenant for imputed interest payments on the Chonsei deposit. If the landlord does not return the Chonsei deposit at the end of the rental term, the tenant can sue for a foreclosure sale to recover the deposit. ${ }^{7}$

\footnotetext{
${ }^{5}$ www.neonet.co.kr and www.r114.co.kr are market leaders which provide apartment price information through other portal sites and financial institutions as well as through their own sites. One can look up the latest rent and sale prices of any narrowly specified type of apartment (by location, size and vintage) from any Korean internet portal, and from the home pages of newspapers and financial institutions. Recently, Kookmin Bank, www.kbstar.com, the largest commercial bank, began publishing its own apartment price surveys. These and other providers usually update their prices weekly or bi-weekly. The popularity of apartment price information reflects the intense interest among Koreans on the investment potential of apartments.

${ }^{6}$ We use Chonsei deposit, Chonsei rent, and Chonsei price interchangeably.

${ }^{7}$ These features of Chonsei contracts are analyzed by Ambrose and Kim (2003).
} 
The continuous housing price inflation, the high interest rates in Korea, and its underdeveloped banking system explain the persistence and the popularity of the Chonsei system. With increasing sale prices and Chonsei prices, tenants need seldom worry about the safe return of the deposit at the end of the rental term.

\section{Impacts of the Asian Financial Crisis}

Our data set covers the period of the Asian Financial Crisis (1997-1998) which had substantial impacts on Korean housing markets. From the last quarter of 1997 to the end of 1998, the nationwide land price index fell by 13.8 percent, the largest drop since the government began keeping records in 1975. The nationwide house sale price index and the Chonsei rent index fell by 13.2 percent and 20.1 percent, respectively. A sharp drop in disposable income, growing uncertainty about the future, and reluctance of banks to make loans on risky projects led to a fall in new housing construction by 48.7 percent in 1998, compared to the previous year. Other indicators of the construction market, such as construction investment, building permits, and new construction contracts, all collapsed.

This crisis provided a backdrop for changes in housing policies, but the Korean housing market was going through important structural changes even before the time of the crisis. Korean housing markets were heavily regulated in earlier years due to chronic shortages of available housing and resulting inflation in house prices. However, together with government-led massive construction in the late 1980s, many regulations in the Korean housing market were gradually eliminated. The economic crisis accelerated the drives for privatization and deregulation as a part of the restructuring package of the Korean macro-economy. Renewed emphasis was placed on developing an adequate housing finance system, starting with the slow introduction of mortgages and mortgage backed securities in the late 1990s, to the privatization of the Korea Housing Bank, which specialized in financing housing construction. $^{8}$

\section{Data and Market Trends}

Our data come from surveys by the Real Estate Bank, ${ }^{9}$ a market leader in the apartment information business. The firm started building a broker-reporter network, publishing a bi-weekly price survey of Seoul apartments in 1988, and later expanded coverage nationally. Currently, most apartments in major cities are covered by its weekly enumeration of sales prices and Chonsei deposits.

An observation (or record) in the data is a "type" of apartment, narrowly identified by series of qualifiers: the location, the name of the apartment complex (which signifies vintage), and the size of the unit. The number of distinct types of apartments in our data increases from 1,192 in 1990 Q1 to 3,354 in 1995 Q2 and to 12,203 in 2002 Q3. Each type may represent hundreds of similar units. For example, each distinct apartment type in our data in 2002 represents 177 units on average. We use end-of-quarter data for capital region apartments from the first

\footnotetext{
${ }^{8}$ For detailed accounts of recent developments of the Korean housing finance system, see Kim (2000). For a complete review of housing policy changes in response to the crisis, see Son et al. (2003).

${ }^{9}$ www.neonet.co.kr

Springer
} 
Table 1 Distribution of housing types and housing units by size and region (number of housing units in parentheses) 1990 Q1-2002 Q3

\begin{tabular}{llllll}
\hline & Small & Medium-small & Medium-large & Large & Total \\
\hline Seoul & 54 & 169 & 343 & 185 & 751 \\
Region 1 & $(3,919)$ & $(21,177)$ & $(45,658)$ & $(16,898)$ & $(87,652)$ \\
Seoul & 133 & 446 & 769 & 243 & 1,591 \\
Region 2 & $(39,814)$ & $(93,801)$ & $(143,535)$ & $(30,957)$ & $(308,107)$ \\
Seoul & 141 & 291 & 687 & 424 & 1,543 \\
Region 3 & $(67,559)$ & $(39,718)$ & $(116,167)$ & $(43,968)$ & $(267,412)$ \\
Seoul & 93 & 447 & 754 & 303 & 1,597 \\
Region 4 & $(21,117)$ & $(65,126)$ & $(118,449)$ & $(31,526)$ & $(236,218)$ \\
Kyunggi & 71 & 468 & 682 & 325 & 1,546 \\
Region 1 & $(15,884)$ & $(104,235)$ & $(138,939)$ & $(44,592)$ & $(303,650)$ \\
Kyunggi & 453 & 1,265 & 1,404 & 595 & 3,717 \\
Region 2 & $(110,680)$ & $(253,282)$ & $(269,270)$ & $(71,014)$ & $(704,246)$ \\
Incheon & 280 & 727 & 605 & 164 & 1,776 \\
& $(52,949)$ & $(103,092)$ & $(122,002)$ & $(19,788)$ & $(297,831)$ \\
Total & 1,225 & 3,813 & 5,244 & 2,239 & 12,521 \\
& $(311,922)$ & $(680,431)$ & $(954,020)$ & $(258,743)$ & $(2,205,116)$ \\
\hline
\end{tabular}

Notes:

"Small" apartments are those with less than 645 sq.ft.

"Medium-Small" are those with 645-914 sq.ft.

"Medium-Large" are those with 915-1429 sq.ft.

"Large" are those with more than 1430 sq.ft.

quarter of 1990 to the third quarter of 2002. We analyze prices and rents for these various housing types for seven geographical submarkets in the capital region. These submarkets are rather distinct in terms of history, industrial composition, and housing market development. Figure 1 indicates the seven submarkets: four are located within metropolitan Seoul, two are in Kyunggi province, and one includes the city of Inchon. Appendix A describes these geographical regions in more detail. Table 1 reports the distribution of apartment types by submarket and size. For any size category and region, the number of apartment types varies from 54, representing 3,919 units, to 769, representing 143,535 units. Altogether there are more than 12,000 types in the data set, representing more than two million dwellings in the capital region. For various reasons, we do not have a continuous time series for all of the apartment types represented in Table 1 for the 1990-2002 period. $^{10}$ Table 2 reports the number of housing types observed continuously during the sample period up to the Asian Financial Crisis of 19971998, and the number observed continuously after the end of the crisis (i.e., since 1999).

To calculate the implicit rent from the Chonsei deposit, we use the average of one-year and three-year Korean Industrial Finance bond rates (since neither government bonds nor Bank of Korea bonds of any maturity cover the entire data

\footnotetext{
${ }^{10}$ The data collection started as a modest operation at first and later added more areas and apartments; many apartments were newly built or demolished for re-construction in this period; some observations were deleted for suspected errors in our verification process.
} 
Table 2 Distribution of apartment types and housing units observed continuously: before the Asian financial crisis (1990 Q1-1997 Q3) and after the Asian financial crisis (1999 Q1-2002 Q3)

\begin{tabular}{lccccc}
\hline & Small & $\begin{array}{l}\text { Medium- } \\
\text { small }\end{array}$ & $\begin{array}{l}\text { Medium- } \\
\text { large }\end{array}$ & Large & Total \\
\hline Seoul & $5(232)$ & $11(2,772)$ & $23(4,402)$ & $12(2,514)$ & $51(9,920)$ \\
Region 1 & $6(272)$ & $49(9,032)$ & $125(23,084)$ & $56(7,752)$ & $236(40,140)$ \\
Seoul & $32(10,128)$ & $54(14,396)$ & $86(20,254)$ & $21(2,988)$ & $193(47,766)$ \\
Region 2 & $93(29,546)$ & $208(55,022)$ & $363(89,430)$ & $94(15,333)$ & $758(189,331)$ \\
Seoul & $52(30,800)$ & $44(9,331)$ & $154(45,367)$ & $136(22,301)$ & $386(107,799)$ \\
Region 3 & $75(48,756)$ & $146(27,695)$ & $395(90,336)$ & $225(34,688)$ & $841(201,475)$ \\
Seoul & $23(5,997)$ & $61(6,093)$ & $93(16,199)$ & $23(3,351)$ & $200(31,640)$ \\
Region 4 & $49(14,104)$ & $156(30,217)$ & $299(67,666)$ & $95(15,893)$ & $599(127,880)$ \\
Kyunggi & $8(2,365)$ & $5(891)$ & $0(0)$ & $0(0)$ & $13(3,256)$ \\
Region 1 & $34(7,162)$ & $199(52,263)$ & $291(64,133)$ & $117(17,341)$ & $641(140,899)$ \\
Kyunggi & $47(13,299)$ & $48(8,252)$ & $61(14,753)$ & $3(526)$ & $159(36,830)$ \\
Region 2 & $240(72,167)$ & $472(104,898)$ & $664(147,763)$ & $326(41,497)$ & $1702(366,325)$ \\
Incheon & $2(246)$ & $7(1,032)$ & $9(3,164)$ & $3(390)$ & $21(4,832)$ \\
& $48(13,027)$ & $131(28,903)$ & $203(59,961)$ & $70(8,604)$ & $452(110,495)$ \\
Total & $169(63,067)$ & $230(42,767)$ & $426(104,139)$ & $198(32,070)$ & $1,023(242,043)$ \\
& $545(185,034)$ & $1,361(308,030)$ & $2,340(542,373)$ & $983(141,108)$ & $5,229(1,176,545)$ \\
\hline
\end{tabular}

Notes:

The first line reports the number of housing types in each submarket observed continuously for the period 1990 Q1 through 1997 Q3. The second line reports the number of housing types in each submarket observed continuously for the period 1999 Q1 through 2002 Q3.

In parentheses are the number of units in each submarket observed continuously for the sample period.

period). The bonds issued by the government-owned Korean Industrial Bank are accepted as risk free in Korean bond markets. In addition to the two-year return, we also compute quarterly returns, using the three-month CD rate. ${ }^{11}$ Figure 2 reports trends in average sale prices, Chonsei deposits and implicit rents. ${ }^{12}$ It shows that the sharp housing inflation of the late 1980s continued until mid-1991, and then declined through 1996. The decline of nominal house prices was mild, but in real terms, both sale prices and Chonsei deposits fell substantially from their peak. ${ }^{13}$ The market showed signs of a boom in early 1997, but the Asian economic crisis hit hard in Korea late that year. Our data set shows that the average sale price of apartments in

\footnotetext{
${ }^{11}$ Even though the investment horizon of two years is the legal constraint on Chonsei contracts, it is perfectly possible to invest in the housing market with a shorter horizon. The owner of a housing unit can sell the house rented on a Chonsei contract, and the new owner may simply take over the existing Chonsei contract.

${ }^{12}$ In Fig. 2A, B, the rent is calculated for two-year intervals. The figure reports the unweighted mean of each variable.

${ }^{13}$ At the end of 1997, the nationwide sale price index was 63.3 percent of its 1990 value, and the Chonsei index was 84.7 percent in real terms. This pattern of gradual decline in real housing prices was much different from that of Japan and other Asian countries, where a sharp rise and sudden collapse of property prices was attributed to a property price bubble.
} 


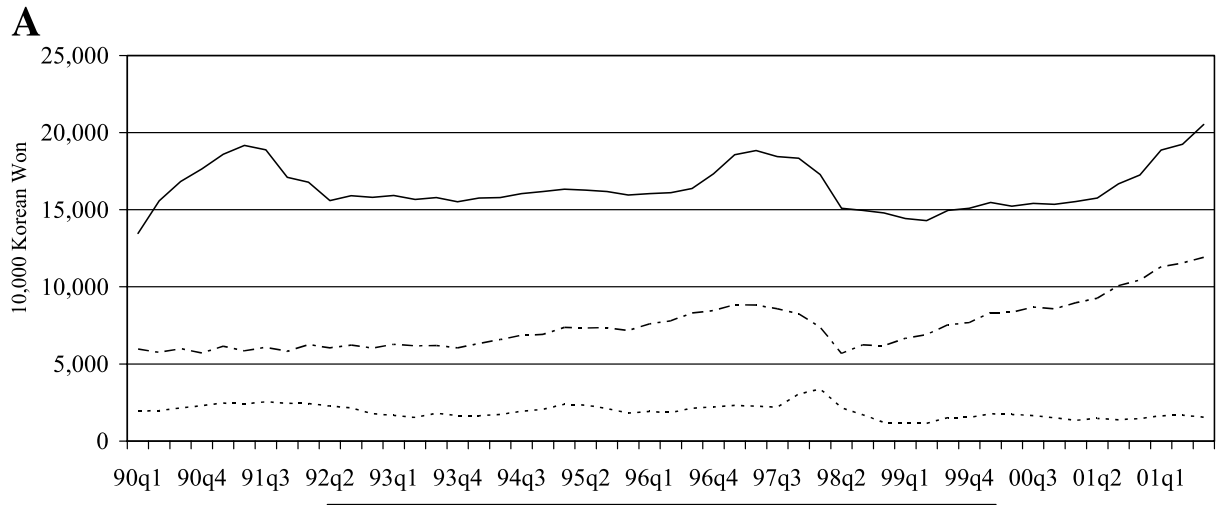

B

$-\cdot$ Chonsei Deposit - Sale price $\cdots \cdot$ Imputed rent

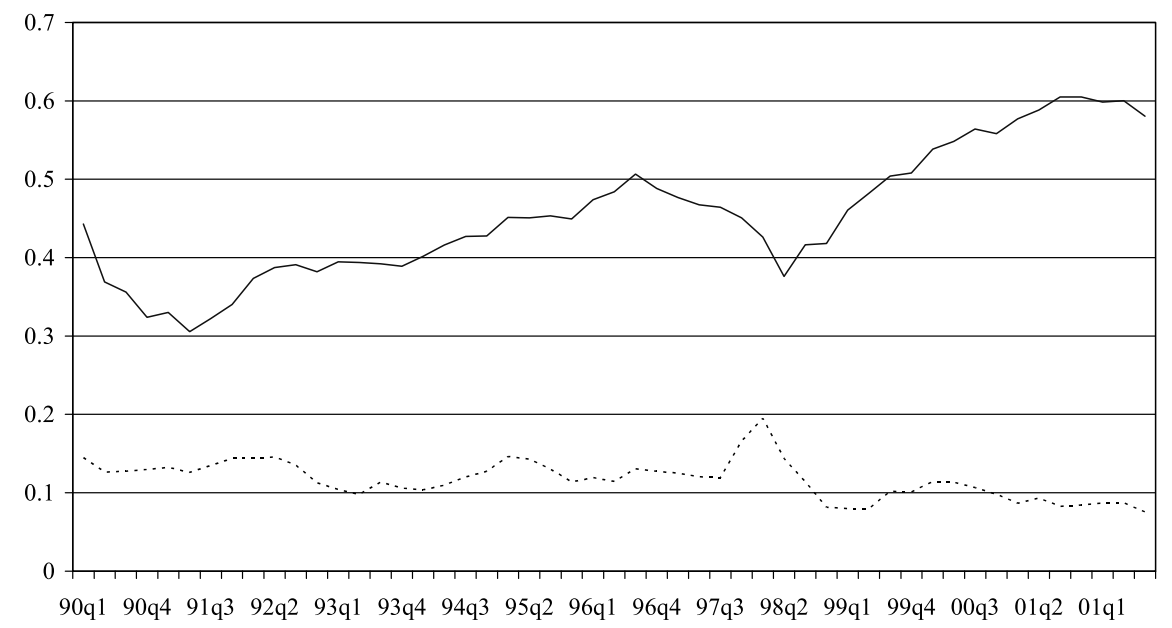

Chonsei Deposit/Sale price

Imputed rent / Sale price

Fig. 2 (A) Means of sale prices, Chonsei deposits, and two-year imputed rents. (B) Chonsei deposits and two-year imputed rents relative to sales prices

the Seoul metropolitan area dropped by 22 percent and Chonsei prices dropped by more than 40 percent in the first half of 1998.

Movements of Chonsei deposits roughly follow those of sale prices, with some significant differences. The asset price bubble for apartments burst in 1991, but there is no corresponding "bulge" in the Chonsei trend. In the mid-1990s, sale prices remained stable, but Chonsei prices continued to rise. Also, Chonsei prices recovered much faster than sale prices after the economic crisis of the late 1990s. These differences arise because Chonsei prices reflect the market for residential services flows rather than the stocks of investment assets. Expected capital gains affect sale prices, but not Chonsei deposits. The same logic (i.e., that the real estate market tends to be more stable than other asset markets) may explain the greater stability of the trends in implicit rents. 


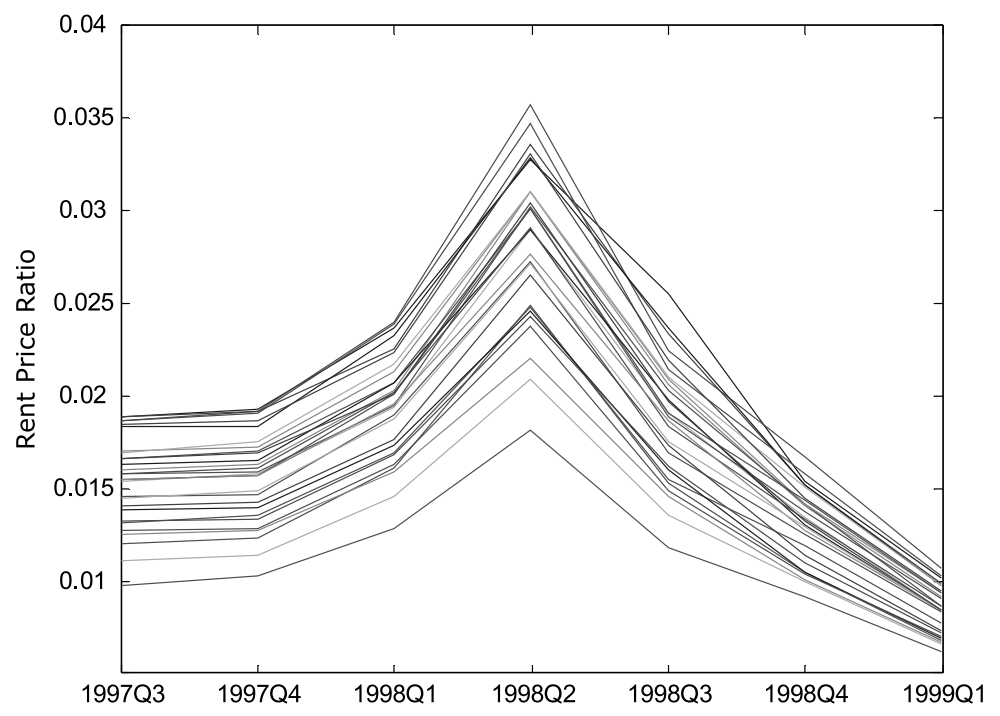

Fig. 3 Rent-price ratios during the Asian financial crisis 1997Q3-1999Q1

As noted in the previous section, the Asian Financial Crisis had a substantial impact on Korean housing markets. Figures 3-5 report the dramatic changes in rent-sales price ratios, rental growth rates, and housing investment returns during the period of the crisis. Figure 3 reports quarterly movements of the average rentprice ratio, 1997Q3-1999Q1, in each panel, differentiated by location and dwelling

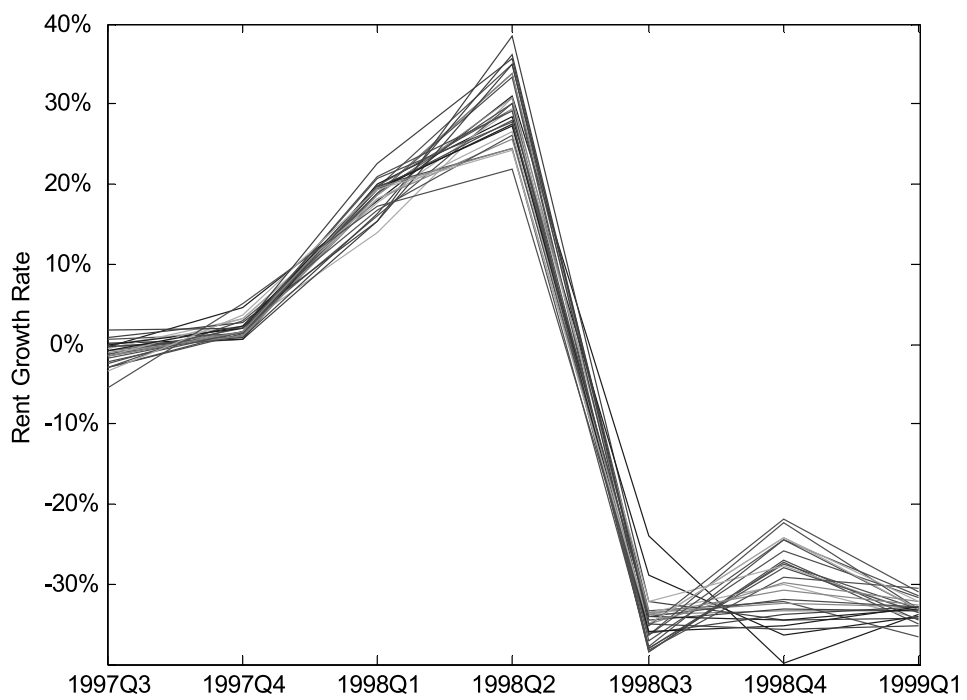

Fig. 4 Rent growth rates during the Asian financial crisis 1997Q3-1999Q1

解 Springer 
size. Almost all the rent-price ratios show the same pattern; rent-price ratios initially rose and then plummeted during the second quarter of 1998. Since sales prices and Chonsei deposits both fell after the onset of the crisis in late 1997, the figure illustrates how rents fell further than asset prices, indicating that the immediate impacts of the crisis fell on demand for housing service first. Figure 4 shows average rental growth rates in the various housing types. Consistent with Fig. 3, average rents fell dramatically after the second quarter of 1998. Indeed, the level of average rents in the latter period is about 35 percent lower. The patterns of rent development are quite similar among different panels. Figure 5 shows average housing returns in different panels around the crisis. Unlike rent-price ratios and rent growth rates, housing returns show more diverse patterns. Even though all the panels experienced losses, some housing types suffered greater short-term losses (more than ten percent) than others (as little as two percent).

Tables 3, 4, and 5 provide similar evidence of the strikingly different performance of the market before the Crisis of 1998 began and after it had ended. Table 3 reports the average rent-price ratios of each panel before the crisis and after the crisis. The ratio of monthly rents to selling prices for condominiums averaged about 1.5 percent during the period before the financial crisis, and only about 0.9 percent after the crisis. In each of the various submarkets, rent-price ratios dropped after the crisis, usually by forty or fifty percent. There are much smaller differences in housing returns before and after the crisis. Before 1998, quarterly returns averaged about three percent; after 1998, they averaged about four percent. As noted in Table 5, there are consistent differences in rental growth rates for apartments between the two periods. The quarterly growth rates for rents were almost two percent during the 1990-1997 period and were negative during the 1999-2002 period. For each of the submarkets, rental growth before the Asian Financial Crisis exceeded the post crisis growth rates.

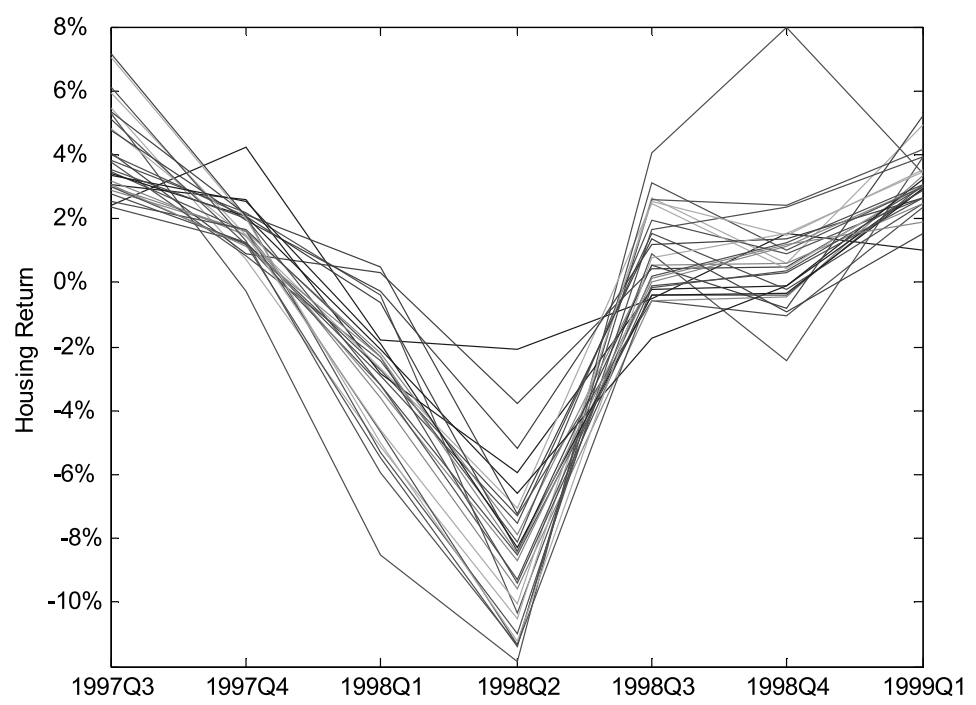

Fig. 5 Housing returns during the Asian financial crisis 1997Q3-1999Q1 
Table 3 Average rent-price ratios by submarket and dwelling size: before the Asian financial crisis and after the Asian financial crisis

\begin{tabular}{llllll}
\hline & Small & Medium-small & Medium-large & Large & Total \\
\hline Seoul & 0.0176 & 0.0172 & 0.0157 & 0.0135 & 0.0157 \\
Region 1 & 0.0090 & 0.0095 & 0.0086 & 0.0073 & 0.0085 \\
Seoul & 0.0182 & 0.0176 & 0.0152 & 0.0128 & 0.0161 \\
Region 2 & 0.0106 & 0.0104 & 0.0092 & 0.0073 & 0.0094 \\
Seoul & 0.0137 & 0.0166 & 0.0153 & 0.0126 & 0.0143 \\
Region 3 & 0.0063 & 0.0083 & 0.0079 & 0.0070 & 0.0076 \\
Seoul & 0.0156 & 0.0165 & 0.0158 & 0.0127 & 0.0156 \\
Region 4 & 0.0096 & 0.0096 & 0.0087 & 0.0070 & 0.0088 \\
Kyunggi & 0.0167 & 0.0158 & & & 0.0066 \\
Region 1 & 0.0091 & 0.0096 & 0.0084 & 0.0124 & 0.0163 \\
Kyunggi & 0.0173 & 0.0167 & 0.0160 & 0.0071 & 0.0165 \\
Region 2 & 0.0091 & 0.0098 & 0.0089 & 0.0125 & 0.0089 \\
Incheon & 0.0182 & 0.0167 & 0.0163 & 0.0077 & 0.0092 \\
& 0.0099 & 0.0098 & 0.0091 & 0.0127 & 0.0154 \\
Total & 0.0161 & 0.0168 & 0.0155 & 0.0071 & 0.0087 \\
\hline
\end{tabular}

Note:

The first line for each region and size reports the average rent-price ratio for dwellings during the period 1990 Q1 through 1997 Q3. The second line reports the average rent-price ratios for dwellings during the period 1998 Q1 through 2002 Q3.

\section{Cross Sectional Characteristics of Investment Returns and the Time Series Properties of Dividend-Price Ratios}

\section{Cross Section}

We describe cross sectional characteristics of returns to housing investment by a series of descriptive regressions:

$$
R_{i, t}=\beta_{0}+\beta_{S}^{\prime} S_{i, t}+\beta_{L}^{\prime} L_{i, t}+\beta_{1} R_{i, t-1}+\beta_{2}\left(P_{i, t-1} / D_{i, t-1}\right)+\beta_{3}\left(P_{i, t-1} / W_{i}\right)+\varepsilon_{i, t},
$$

where $R_{i, t}$ is the two-year return on housing type $i$ at $t, S_{i, t}$ are dummy variables for sizes, $L_{i, t}$ are dummy variables for regions, $\left(P_{i, t-1} / D_{i, t-1}\right)$ is the price-deposit ratio (i.e., selling prices divided by Chonsei prices), and $\left(P_{i, t-1} / W_{i}\right)$ is the price per square foot.

The regression is estimated for each cross section of two-year returns starting from the first quarter of 1994. Table 6 reports the results. The explained variance for each cross-section is substantial, ranging between 0.2 and 0.5 . Except for the periods during the Asian Financial Crisis (1998), a substantial portion of the cross sectional variation can be explained by variables signifying housing type, submarket, lagged returns, and prices. Second, lagged returns are generally quite significant; this implies that apartment types with lower returns in the previous period tend to have higher returns in the current period than do apartment types with higher returns in 
Table 4 Gross quarterly housing returns by submarket and dwelling size: before the Asian financial crisis and after the Asian financial crisis

\begin{tabular}{llllll}
\hline & Small & Medium-small & Medium-large & Large & Total \\
\hline Seoul & 1.0246 & 1.0287 & 1.0241 & 1.0241 & 1.0252 \\
Region 1 & 1.0331 & 1.0396 & 1.0352 & 1.0274 & 1.0342 \\
Seoul & 1.0404 & 1.0266 & 1.0255 & 1.0196 & 1.0276 \\
Region 2 & 1.0452 & 1.0405 & 1.0359 & 1.0264 & 1.0371 \\
Seoul & 1.0415 & 1.0317 & 1.0262 & 1.0240 & 1.0281 \\
Region 3 & 1.0760 & 1.0638 & 1.0582 & 1.0443 & 1.0571 \\
Seoul & 1.0323 & 1.0283 & 1.0257 & 1.0233 & 1.0270 \\
Region 4 & 1.0502 & 1.0444 & 1.0413 & 1.0338 & 1.0416 \\
Kyunggi & 1.0356 & 1.0320 & - & - & 1.0342 \\
Region 1 & 1.0433 & 1.0363 & 1.0303 & 1.0229 & 1.0315 \\
Kyunggi & 1.0425 & 1.0341 & 1.0314 & 1.0259 & 1.0354 \\
Region 2 & 1.0522 & 1.0412 & 1.0377 & 1.0299 & 1.0392 \\
Incheon & 1.0310 & 1.0293 & 1.0303 & 1.0277 & 1.0296 \\
& 1.0426 & 1.0417 & 1.0430 & 1.0357 & 1.0415 \\
Total & 1.0394 & 1.0299 & 1.0267 & 1.0236 & 1.0289 \\
& 1.0525 & 1.0432 & 1.0407 & 1.0327 & 1.0411 \\
\hline
\end{tabular}

Note:

The first line for each region and size reports the average quarterly return for dwellings during the period 1990 Q1 through 1997 Q3. The second line reports the average quarterly return during the period 1998 Q1 through 2002 Q3.

Gross housing return, $r$, is defined as, $r_{i, t}=\frac{P_{i, t}+R_{i, t}}{P_{i, t}}$ for quarter $t$ and housing $i$, where $P$ represents selling price and $R$ represents rent.

Table 5 Quarterly growth rate in rents by submarket and dwelling size: before the Asian financial crisis and after the Asian financial crisis

\begin{tabular}{llllll}
\hline & Small & Medium-small & Medium-large & Large & Total \\
\hline Seoul & 1.0189 & 1.0170 & 1.0145 & 1.0151 & 1.0156 \\
Region 1 & 0.9790 & 0.9928 & 0.9957 & 0.9964 & 0.9948 \\
Seoul & 1.0188 & 1.0213 & 1.0208 & 1.0196 & 1.0205 \\
Region 2 & 0.9976 & 0.9985 & 1.0000 & 0.9933 & 0.9985 \\
Seoul & 1.0189 & 1.0171 & 1.0187 & 1.0191 & 1.0186 \\
Region 3 & 0.9971 & 0.9994 & 1.0020 & 1.0027 & 1.0013 \\
Seoul & 1.0151 & 1.0185 & 1.0165 & 1.0157 & 1.0168 \\
Region 4 & 0.9970 & 0.9986 & 1.0032 & 1.0007 & 1.0011 \\
Kyunggi & 1.0236 & 1.0241 & - & - & 1.0238 \\
Region 1 & 0.9876 & 0.9975 & 1.0002 & 1.0011 & 0.9988 \\
Kyunggi & 1.0210 & 1.0221 & 1.0226 & 1.0238 & 1.0220 \\
Region 2 & 0.9902 & 0.9933 & 0.9977 & 0.9991 & 0.9957 \\
Incheon & 1.0139 & 1.0204 & 1.0181 & 1.0208 & 1.0188 \\
& 1.0010 & 1.0028 & 1.0088 & 1.0031 & 1.0053 \\
Total & 1.0191 & 1.0197 & 1.0189 & 1.0186 & 1.0191 \\
& 0.9937 & 0.9969 & 1.0006 & 0.9999 & 0.9988 \\
\hline
\end{tabular}

Note:

The first line for each region and size reports the average quarterly growth rate for rent for dwellings during the period 1990 Q1 through 1997 Q3. The second line reports the average rental growth rate during the period 1998 Q1 through 2002 Q3. 
Table 6 Cross sectional models of investment returns in Korean apartments: 1994Q1-2002Q3

\begin{tabular}{|c|c|c|c|c|c|}
\hline & 1994:Q1 & 1996:Q1 & 1998:Q1 & 2000:Q1 & 2002:Q2 \\
\hline \multicolumn{6}{|l|}{ Size } \\
\hline Medium-small & $\begin{array}{c}-0.0550 \\
(7.28)\end{array}$ & $\begin{array}{c}-0.0729 \\
(8.16)\end{array}$ & $\begin{array}{l}0.0157 \\
(2.77)\end{array}$ & $\begin{array}{c}-0.0009 \\
(0.17)\end{array}$ & $\begin{array}{l}-0.0677 \\
(12.67)\end{array}$ \\
\hline Medium-large & $\begin{array}{l}-0.0849 \\
(10.80)\end{array}$ & $\begin{array}{l}-0.0903 \\
(10.25)\end{array}$ & $\begin{array}{l}0.0429 \\
(8.15)\end{array}$ & $\begin{array}{c}-0.0151 \\
(2.96)\end{array}$ & $\begin{array}{l}-0.1152 \\
(22.43)\end{array}$ \\
\hline Large & $\begin{array}{c}-0.1042 \\
(8.82)\end{array}$ & $\begin{array}{l}-0.1306 \\
(11.63)\end{array}$ & $\begin{array}{l}0.0311 \\
(4.43)\end{array}$ & $\begin{array}{c}-0.0619 \\
(9.38)\end{array}$ & $\begin{array}{l}-0.2175 \\
(33.17)\end{array}$ \\
\hline \multicolumn{6}{|l|}{ Region } \\
\hline Seoul & 0.0308 & -0.0056 & 0.0239 & 0.0117 & 0.0188 \\
\hline Region 2 & $(2.93)$ & $(0.70)$ & $(4.02)$ & $(1.93)$ & $(3.10)$ \\
\hline Seoul & 0.0287 & 0.0841 & 0.0522 & 0.0902 & 0.1721 \\
\hline Region 3 & $(2.83)$ & $(10.46)$ & $(8.24)$ & $(14.85)$ & $(25.93)$ \\
\hline Seoul & 0.0269 & 0.0481 & 0.0474 & 0.0187 & 0.0780 \\
\hline Region 4 & $(2.58)$ & $(5.93)$ & $(7.33)$ & $(2.96)$ & $(12.06)$ \\
\hline Kyunggi & -0.0420 & 0.0813 & 0.1060 & 0.0470 & 0.0200 \\
\hline Region 1 & $(2.20)$ & $(4.58)$ & $(10.02)$ & $(6.17)$ & $(3.23)$ \\
\hline Kyunggi & 0.0508 & 0.1118 & 0.1106 & 0.0670 & 0.0526 \\
\hline Region 2 & $(4.11)$ & $(10.25)$ & $(16.25)$ & $(10.33)$ & $(8.93)$ \\
\hline Incheon & $\begin{array}{l}0.0128 \\
(0.81)\end{array}$ & $\begin{array}{c}0.0789 \\
(6.61)\end{array}$ & $\begin{array}{c}0.0902 \\
(10.26)\end{array}$ & $\begin{array}{c}0.0733 \\
(9.67)\end{array}$ & $\begin{array}{c}0.1544 \\
(21.05)\end{array}$ \\
\hline Lagged & -0.2545 & 0.1048 & -0.1365 & -0.3574 & 0.0290 \\
\hline Return & $(11.45)$ & $(3.97)$ & $(7.30)$ & $(17.92)$ & $(1.77)$ \\
\hline Lagged & -0.0805 & -0.1312 & -0.1091 & -0.1073 & -0.1681 \\
\hline Price/deposit & $(3.73)$ & (7.07) & $(8.47)$ & $(10.46)$ & $(13.50)$ \\
\hline Lagged & -0.0412 & 0.1196 & 0.0491 & 0.1010 & 0.0828 \\
\hline Price/size & $(3.28)$ & $(9.86)$ & $(5.68)$ & $(14.40)$ & $(12.80)$ \\
\hline Adj $R^{2}$ & 0.4257 & 0.3215 & 0.1779 & 0.3316 & 0.5141 \\
\hline Number of observations & 1170 & 2276 & 2941 & 3949 & 5294 \\
\hline
\end{tabular}

Note:

Standard errors are corrected for heteroskedasticity using White (1980). T-statistics are given in parentheses.

the previous period. ${ }^{14}$ Third, the lagged price/deposit ratio also significantly predicts the current returns. The lagged price/deposit ratio measures market expectations of future price appreciation. Note that apartment types with larger expected appreciation in prices tend to have higher price-deposit ratios. If this expectation were correct, then a higher price-deposit ratio would be positively correlated with the returns in the next period. However, the estimated coefficients are consistently negative, implying that housing units with lower expected returns tend to outperform those units with higher expected returns. Fourth, coefficients on lagged price per square foot are also significantly positive; units with higher prices last period tend to exhibit high returns in the current period.

Taken together, these cross section regressions suggest a profitable ex-post investment strategy during this period: Buy dwelling units with low current returns, low price/deposit ratios and high prices per square foot.

\footnotetext{
${ }^{14}$ It does not imply that lower returns for a given type predict higher returns for the same type in the next period.
}

Springer 
The dummy variables classifying the capital region into seven submarkets are highly significant. Except for the period of the Asian Financial Crisis (1998), the apartment types in the smallest size group exhibit the highest returns. Moreover, size and returns tend to move in opposite directions: the larger the apartment types, the lower the expected returns. The results suggest that Seoul Region 3, the area south of the Han River, consistently generates the highest returns within Seoul. The difference in returns between this and the other regions also tends to grow larger over time. Among the non-Seoul regions, Kyunggi Region 1 tends to generate the highest returns in early years, but after the Asian Financial Crisis, Incheon exhibits the highest investment returns.

\section{Time Series: Unit Roots}

As reported in Table 2, the sample includes many panels of housing units observed continuously during the 1990-1997 period, and a large number of panels observed after the Asian Financial Crisis of 1998. For each element in the various panels, we observe prices and dividends quarterly. In this section, we investigate the presence of unit roots in these panels of dividend price ratios.

There are many versions of panel unit root tests; we adopt the test proposed by Chang and Song (2003). Their procedure has several advantages for our purposes. It accounts for cross sectional correlations in innovations and the presence of cointegration among cross sectional units. In addition, the test can also analyze unbalanced panels, and more sophisticated hypotheses can be formulated. In testing for the presence of unit roots in our panels, we employ the null hypothesis that at least ten percent of the individual apartment types have unit roots in price-rent ratios. (Note that this hypothesis is far more difficult to reject than the more typical hypothesis that all the individual types have unit roots).

Tables 7A and 7B present panel unit root tests for the housing types in each of the submarkets. Panel A refers to the period before the Asian Financial Crisis, 1990 1997, while Panel B refers to the period after the crisis, 1999-2002. For the former period, the presence of a unit root in ten percent or more of the series is soundly rejected for 24 of the 28 submarkets. For three of the other submarkets, the hypothesis is rejected at about the 0.1 level. For only one of the submarkets, medium small apartments in Seoul Region 3, is the hypothesis clearly accepted $(\rho=0.32) .{ }^{15}$

The results are almost as strong for the period after the Asian Financial Crisis. The hypothesis that at least ten percent of the dividend-price series have unit roots can be rejected at the five percent level in 15 of the 28 submarkets, at the 10 percent level in another 7 of the submarkets. In only four of the submarkets, is the hypothesis clearly not rejected. ${ }^{16}$

\footnotetext{
${ }^{15}$ However, if the null hypothesis is relaxed to test the hypothesis that the log of price-rent ratios for less than 25 percent of housing types in the market have unit roots, they hypothesis is rejected by a comfortable margin in 27 submarkets and with $\rho=0.08$ in the remaining submarket.

${ }^{16}$ Even here, if the null hypothesis is relaxed to test the hypothesis that the log of price-rent ratios for less than half of the housing types in a submarket have unit roots, the hypothesis is rejected by a comfortable margin in 27 of the 28 submarkets.
} 
Table 7A Panel unit root tests on the log of price-rent ratios for Korean apartments 1990 Q1-1997 Q3 (one quarter lag)

\begin{tabular}{lcccc}
\hline & Small & Medium-small & Medium-large & large \\
\hline Seoul & -1.467 & -2.2672 & -0.9101 & -2.457 \\
Region 1 & $(0.07)$ & $(<0.01)$ & $(<0.01)$ & $(<0.01)$ \\
Seoul & 0.1529 & -1.2006 & -0.8037 & -1.5864 \\
Region 2 & $(0.10)$ & $(0.00)$ & $(0.00)$ & $(<0.01)$ \\
Seoul & 0.5656 & 0.8347 & 0.406 & -1.212 \\
Region 3 & $(0.13)$ & $(0.32)$ & $(<0.01)$ & -1.4888 \\
Seoul & -0.6077 & -0.0176 & -1.0767 & $(<0.01)$ \\
Region 4 & $(0.02)$ & $(<0.01)$ & $(<0.01)$ & 0 \\
Kyunggi & -1.2852 & -1.561 & 0 & $(<0.01)$ \\
Region 1 & $(0.10)$ & $(0.06)$ & $(<0.01)$ & -1.1823 \\
Kyunggi & 0.2804 & -0.2278 & -0.1135 & $(0.12)$ \\
Region 2 & $(0.08)$ & $(0.01)$ & $(<0.01)$ & -1.7284 \\
Incheon & -3.3284 & -2.342 & -1.8248 & $(0.04)$ \\
& $(<0.01)$ & $(<0.01)$ & $(0.03)$ & \\
\hline
\end{tabular}

Entries in the table are based on regressions for the n-individual apartment types in a given panel, $y_{t}^{n}=\beta_{1}^{n} y_{t-1}+\sum_{i=1}^{K} \beta_{1, i}^{n} \Delta y_{t-i}^{n}+\sum_{i=K+1}^{2 K_{i}} \beta_{2, i}^{n} x_{t+K-i}^{n}+\varepsilon_{t}^{n}$, where $y_{t}^{n}$ is the log of price-rent ratio, and $x_{t}^{n}$ is the difference between the discount rate and rent growth. The table reports tests of $\beta_{1}^{n}=1$, proposed by Chang and Song (2003).

For each cell, modified t-statistics are provided for the null hypothesis that the log of price rent ratios for at least ten percent of housing types in the market have unit roots. P-values are given in parentheses. The number of apartment types associated with each entry in the table is reported in Table 2. For more detailed information on the panel unit root test used, see Chang and Song (2003).

Table 7B Panel unit root tests on the log of price-rent ratios for Korean apartments 1999 Q1-2002 Q3 (one quarter lag)

\begin{tabular}{lcccc}
\hline & Small & Medium-small & Medium-large & Large \\
\hline Seoul & 0.0242 & 0.2845 & 1.0068 & 0.3591 \\
Region 1 & $(0.51)$ & $(0.09)$ & $(0.11)$ & $(0.07)$ \\
Seoul & 0.6573 & 0.9469 & 0.8009 & 0.6759 \\
Region 2 & $(0.05)$ & $(0.02)$ & $(0.00)$ & $(0.06)$ \\
Seoul & 0.9147 & 1.2027 & 1.3605 & 0.8471 \\
Region 3 & $(0.20)$ & $(0.16)$ & $(0.03)$ & $(<0.01)$ \\
Seoul & 1.3373 & 0.8745 & 0.9855 & 0.7727 \\
Region 4 & $(0.62)$ & $(0.03)$ & $(<0.01)$ & $(0.08)$ \\
Kyunggi & 0.0391 & 0.6036 & 0.7997 & 0.7987 \\
Region 1 & $(0.07)$ & $(<0.01)$ & $(<0.01)$ & $(0.06)$ \\
Kyunggi & 1.0417 & 1.0287 & 1.0233 & 0.862 \\
Region 2 & $(0.02)$ & $(<0.01)$ & $(<0.01)$ & $(<0.01)$ \\
Incheon & 0.355 & 0.9046 & 0.971 & 0.1903 \\
& $(0.11)$ & $(0.06)$ & $(0.02)$ & $(0.02)$ \\
\hline
\end{tabular}

Entries in the table are based on regressions for the n-individual apartment types in a given panel, $y_{t}^{n}=\beta_{1}^{n} y_{t-1}+\sum_{i=1}^{K} \beta_{1, i}^{n} \Delta y_{t-i}^{n}+\sum_{i=K+1}^{2 K_{i}} \beta_{2, i}^{n} x_{t+K-i}^{n}+\varepsilon_{t}^{n}$, where $y_{t}^{n}$ is the log of price-rent ratio, and $x_{t}^{n}$ is the difference between the discount rate and rent growth. The table reports tests of $\beta_{1}^{n}=1$, proposed by Chang and Song (2003).

For each cell, modified t-statistics are provided for the null hypothesis that the log of price rent ratios for at least ten percent of housing types in the market have unit roots. P-values are given in parentheses. The number of apartment types associated with each entry in table is reported in Table 2. For more detailed information on the panel unit root test used, see Chang and Song (2003). 


\section{Tests of the Dividend Price Ratio Model}

For a given investment horizon and for an individual house, define the expected total rate of return $r_{t+1 \mid t}^{e}$ at time $t$, where price is $P_{t}$ and the dividend (rent) is $D_{t+1}$, computed as the proceeds from the risk-free investment of the Chonsei deposit received in the previous period. Rent is received at the end of the period, but is known at the beginning of the period.

$r_{t+1 \mid t}^{e}=E_{t}\left(r_{t+1}\right)=\frac{E_{t}\left(P_{t+1}-P_{t}\right)+D_{t+1}}{P_{t}}$

In equilibrium, the expected return $r_{t+1 \mid t}^{e}$ will reflect various risk factors and costs associated with the investment. ${ }^{17}$ Large transaction costs and limited liquidity, high information costs, and high property taxes will all require higher expected returns from housing investment. Individual houses may have distinct risk-return characteristics, but similar dwellings share the same risk-cost characteristics and the same expected rate of return.

Equation (2) can be solved forward to yield

$P_{t}=\sum_{J=1}^{\infty} E_{t}\left[\left(\prod_{j=1}^{J} \frac{1}{1+r_{t+j \mid t}^{e}}\right) R_{t+J}\right]$.

With constant discount rates, this can be simplified to

$P_{t}=\sum_{J=1}^{\infty} E_{t}\left[\frac{R_{t+J}}{(1+r)^{J}}\right]$.

There are many ways to test this relationship in financial markets. ${ }^{18}$ Here we test whether the current price is an adequate forecast of future dividends, following Campbell and Shiller (1988). ${ }^{19}$ The Campbell-Schiller test was originally applied in a univariate context using U.S. stock market indices over long horizon; we use panels of apartment investment returns instead over shorter time horizons. The major advantages from analyzing panels of returns are obvious: panels permit more powerful tests with more observations; panels permit the analysis of cross sectional correlations among returns. More importantly, by using panels, we can match rents and prices for the same dwellings over time, matching asset prices and dividends exactly. (See Meese and Wallace, 1994, for the difficulties of unmatched samples).

As demonstrated in Section 3, investment returns in Korean housing markets vary geographically and by size of dwelling, and there is a clean break with the

\footnotetext{
${ }^{17}$ For housing, equilibrium rent equals the user cost of homeownership less the expected capital gain, $R_{t+1}=[\delta+\kappa+(1-\theta)(i+\mu)+\alpha] P_{t}-E_{t}\left(P_{t+1}-P_{t}\right)$ where $\delta$ is the depreciation rate, $\kappa$ is the maintenance rate, $\theta$ is the marginal income tax rate, $\mu$ is the property tax rate and $\alpha$ is a risk premium. (See Poterba, 1984).

${ }^{18}$ For reviews of earlier tests, see LeRoy (1989) and Gilles and LeRoy (1991).

${ }^{19}$ Diba and Grossman (1988), Hamilton and Whiteman (1985), Campbell and Shiller (1987), and Craine (1993).
} 
Asian Financial Crisis of 1997-1998. Thus, it appears natural to define panels by region and dwelling size. Also, as indicated in Section 3, panels so constructed do not exhibit unit roots in dividend price ratios. This makes the test of the dividendprice ratio model on these panels quite natural (as the test relies upon stationarity in the dividend-price ratio).

We analyze quarterly returns using the panels summarized in Table 2. Consider a test of the "dividend-price ratio model." Let $r_{t+1}$ be the log of the gross return to an apartment,

$r_{t+1} \equiv \log \left(P_{t+1}+D_{t+1}\right)-\log \left(P_{t}\right)=p_{t+1}-p_{t}+\log \left(1+\exp \left(d_{t+1}-p_{t+1}\right)\right)$,

where $P_{t}$ is a price, and $D_{t}$ is the dividend imputed from the Chonsei deposit.

By approximating (4) around its mean, solving the equation forward and adjusting for unconditional means,

$d_{t}-p_{t}=\sum_{j=0}^{\infty} \rho^{j}\left(r_{t+i+j}-\Delta d_{t+1+j}\right)$,

where $\rho=\frac{1}{1+\exp (\bar{d}-\bar{p})}$, and where the bars represent unconditional expectations. Since (5) holds ex post, for a given discount rate,

$d_{t}-p_{t}=\sum_{j=0}^{\infty} \rho^{j} E_{t}\left[r_{t+i+j}-\Delta d_{t+1+j}\right]$.

To test (6) with given discount rates, it is necessary to specify the stochastic processes governing dividend price ratios and dividend growth rates to compute the conditional expectations. Campbell and Shiller (1988) propose a VAR approach to identify these conditional expectations. Assume $x_{t}=[d t-p t, r t-\Delta d t]^{\prime}$ follows a $\mathrm{p}$-th order bi-variate VAR process,

$x_{t}=\sum_{k=1}^{p} C_{k} x_{t-k}+u_{t}$,

where $C_{k}$ is a $2 \times 2$ matrix for $k=1,2, \ldots, p$. Equation (7) can be expressed as (Hamilton 1994)

$z_{t}=A z_{t-1}+v_{t}$

where $z_{t}=\left[\left(d_{t}-p_{t}\right), \ldots,\left(d_{t-p-1}-p_{t-p-1}\right),\left(r_{t}-\Delta d_{t}\right), \ldots,\left(r_{t-p-1}-\Delta d_{t-p-1}\right)\right]$ and is a $(2 p \times 1)$ vector. To identify $\left(d_{t}-p_{t}\right)$ and $\left(r_{t}-\Delta d_{t}\right)$ in $z_{t}$, we define $e_{p}$, a $(2 p \times 1)$ vector whose $\mathrm{p}$-th element is one while all the other elements are zero, so that $d_{t}-p_{t}=e_{1} z_{t}$ and $r_{t}-\Delta d_{t}=e_{p} z_{t}$,

$e_{1} z_{t}=\sum_{j=0}^{\infty} \rho^{j} e_{p} A^{j+1} z_{t}$.

Springer 
This notation immediately suggests a testable restriction,

$e_{1}^{\prime}=e_{p}^{\prime} A(I-\rho A)^{-1}=\left(e_{p}^{\prime}+\rho e_{1}^{\prime}\right) A$.

or equivalently,

$R \beta=e_{1}$,

where $R=\left[\rho I_{p}, I_{p}\right], \beta=\left[A_{1}, A_{p}\right]^{\prime}$, and $A_{p}$ is the p-th row of the coefficient matrix $A$ in (8).

It is straightforward to test equation (10) in a panel context. Stacking up the $\mathrm{N}$ apartment types, a panel version of (10) is

$$
\left[\begin{array}{cccc}
R & 0 & \cdots & 0 \\
0 & R & \cdots & 0 \\
\vdots & \vdots & \vdots & \vdots \\
0 & 0 & \cdots & R
\end{array}\right]\left[\begin{array}{c}
\beta_{1} \\
\beta_{2} \\
\vdots \\
\beta_{N}
\end{array}\right]=\left[\begin{array}{c}
e_{1} \\
e_{2} \\
\vdots \\
e_{N}
\end{array}\right]
$$

where $\beta_{i}$ is the coefficient vector for the $\mathrm{i}$-th apartment type in the panel. The number of restrictions is $2 \times \mathrm{p} \times \mathrm{N}$.

To test (10') using panels of apartment returns, we adopt a two-stage procedure. In the first stage, we estimate (8) separately on panels of returns by OLS for each individual type. In the second stage, we estimate (8) on jointly panels of individual returns, using the variance-covariance matrix of error terms estimated from the error terms in the first stage. We assume that in each panel, the error terms for different apartment types have a common component. ${ }^{20}$

Table $8 \mathrm{~A}$ and $8 \mathrm{~B}$ report the results of panel versions of the Dividend Price Ratio Test, estimated separately for the period before and after the Asian Financial Crisis. We use the two-year Industrial Finance Bond rate as the discount rate (implicitly assuming that the risk premium in each period is constant).

We test the null hypothesis that all the apartment types in each submarket are priced by the present value relationship (PVR). The tables report the Chi squared statistics for the test of the present value relationship and the associated $\rho$ value. As noted in Table 8A, for the period preceding the Asian Financial Crisis, for only one of the 26 submarkets is the hypothesis rejected at the 0.05 level. For only one other submarket, is the hypothesis rejected at the 0.10 level. The evidence seems clear: during the period before the Asian Financial Crisis, the present value of dividends does a very good job of explaining the movements in asset prices.

Table $8 \mathrm{~B}$ provides even stronger evidence for the period after the Asian Financial Crisis. For only one submarket-small apartments in one region of Seoul-is the PVR pricing relationship rejected. For the other 27 submarkets, the prices of assets are predicted by the present value of dividends.

For other tests, not reported, based on VAR relationships of different lengths, the results are similar: asset prices are determined by the present discounted value of dividends.

\footnotetext{
${ }^{20}$ Let $\varepsilon$ be a vector of error terms in a factor structure, $\varepsilon=\Lambda f+v$, where $f$ is a common factor and $\Lambda$ is a matrix of factor loadings. Then, under the standard assumption that the factors are independently and normally distributed with zero means and unit variance, $\Sigma$, the covariance matrix of $\varepsilon$, is $\Sigma=\Lambda \Lambda^{\prime}+\Psi$, where $\Psi=E\left(v v^{\prime}\right)$.
} 
Table 8A Dividend price ratio tests for Korean apartments 1990 Q1-1997 Q3

\begin{tabular}{lcccc}
\hline & Small & Medium-small & Medium-large & Large \\
\hline Seoul & 2.8172 & 17.9022 & 35.6926 & 15.8622 \\
Region 1 & $(0.99)$ & $(0.71)$ & $(0.86)$ & $(0.89)$ \\
Seoul & 140.2917 & 100.5198 & 138.9856 & 22.6288 \\
Region 2 & $(0.00)$ & $(0.68)$ & $(0.97)$ & $(0.99)$ \\
Seoul & 102.7530 & 74.7463 & 198.2391 & 168.5990 \\
Region 3 & $(0.52)$ & $(0.84)$ & $(>0.99)$ & $(>0.99)$ \\
Seoul & 27.9790 & 53.5941 & 92.9769 & 31.1811 \\
Region 4 & $(0.98)$ & $(>0.99)$ & - & $(0.95)$ \\
Kyunggi & 15.6000 & 6.6170 & - & - \\
Region 1 & $(0.48)$ & $(0.76)$ & 53.9181 & - \\
Kyunggi & 68.7698 & 46.0817 & $(>0.99)$ & 6.8296 \\
Region 2 & $(0.98)$ & $(>0.99)$ & 13.4533 & $(0.34)$ \\
Incheon & 5.5351 & 5.7769 & $(0.76)$ & 10.8695 \\
& $(0.24)$ & $(0.97)$ & $(0.09)$ \\
\hline
\end{tabular}

Entries in the table are based on one quarter VARs for the $\mathrm{n}$-th individual apartment type in a given panel, $y_{t}^{n}=\alpha_{1,0}^{n}+\sum_{i=1}^{K} \alpha_{1, i}^{n} y_{t-i}^{n}+\sum_{i=K+1}^{2 K} \alpha_{1, i}^{n} x_{t+K-i}^{n}$ and $x_{t}^{n}=\alpha_{2,0}^{n}+\sum_{i=1}^{K} \alpha_{2, i}^{n} y_{t-i}^{n}+\sum_{i=K+1}^{2 K} \alpha_{2, i}^{n} x_{t+K-i}^{n}$, where $y_{t}^{n}$ is log of price-rent ratio, and $x_{t}^{n}$ is the difference between the growth in rent and the discount rate and. Let $\beta_{n}=\left[\alpha_{1,1}^{n}, \cdots, \alpha_{1,2 K}^{n}, \alpha_{2,1}^{n}, \cdots, \alpha_{2,2 K}^{n}\right]^{\prime}$, and $R=[\rho I, I]$. We report results from testing $\left[\begin{array}{cccc}R & 0 & \cdots & 0 \\ 0 & R & \ldots & 0 \\ \vdots & \vdots & \vdots & \vdots \\ 0 & 0 & \cdots & R\end{array}\right]\left[\begin{array}{c}\beta_{1} \\ \beta_{2} \\ \vdots \\ \beta_{N}\end{array}\right]=\left[\begin{array}{c}e_{1} \\ e_{2} \\ \vdots \\ e_{N}\end{array}\right]$.

Each cell reports the $\chi^{2}$-statistic for testing the restriction as well as the p-value, reported in parentheses. The number of apartment types associated with each entry in the table is reported in Table 2 .

Table 8B Dividend price ratio tests for Korean apartments 1999 Q1-2002 Q3

\begin{tabular}{lcllc}
\hline & Small & Medium-small & Medium-large & Large \\
\hline Seoul & 6.0112 & 19.2868 & 85.8322 & 35.2781 \\
Region 1 & $(0.92)$ & $(>0.99)$ & $(>0.99)$ & $(>0.99)$ \\
Seoul & 116.626 & 147.4101 & 234.4822 & 68.0762 \\
Region 2 & $(>0.99)$ & $(>0.99)$ & $(>0.99)$ & $(>0.99)$ \\
Seoul & 184.478 & 159.8249 & 327.4693 & 128.5924 \\
Region 3 & $(0.03)$ & $(>0.99)$ & $(>0.99)$ & $(>0.99)$ \\
Seoul & 41.076 & 118.8154 & 138.2973 & 44.3516 \\
Region 4 & $(>0.99)$ & $(>0.99)$ & $(>0.99)$ & $(>0.99)$ \\
Kyunggi & 26.8437 & 121.0086 & 163.2518 & 70.1723 \\
Region 1 & $(>0.99)$ & $(>0.99)$ & $(>0.99)$ & $(>0.99)$ \\
Kyunggi & 344.504 & 306.7183 & 331.6179 & 196.8353 \\
Region 2 & $(>0.99)$ & $(>0.99)$ & $(>0.99)$ & $(>0.99)$ \\
Incheon & 63.2671 & 114.1579 & 119.0823 & 52.351 \\
& $(>0.99)$ & $(>0.99)$ & $(>0.99)$ & $(>0.99)$ \\
\hline
\end{tabular}

Entries in the table are based on one quarter VARs for the $\mathrm{n}$-th individual apartment type in a given panel, $y_{t}^{n}=\alpha_{1,0}^{n}+\sum_{i=1}^{K} \alpha_{1, i}^{n} y_{t-i}^{n}+\sum_{i=K+1}^{2 K} \alpha_{1, i}^{n} x_{t+K-i}^{n}$ and $x_{t}^{n}=\alpha_{2,0}^{n}+\sum_{i=1}^{K} \alpha_{2, i}^{n} y_{t-i}^{n}+\sum_{i=K+1}^{2 K} \alpha_{2, i}^{n} x_{t+K-i}^{n}$, where $y_{t}^{n}$ is log of price-rent ratio, and $x_{t}^{n}$ is the difference between the growth in rent and the discount rate and. Let $\beta_{n}=\left[\alpha_{1,1}^{n}, \cdots, \alpha_{1,2 K}^{n}, \alpha_{2,1}^{n}, \cdots, \alpha_{2,2 K}^{n}\right]^{\prime}$, and $R=[\rho I, I]$. We report results from testing $\left[\begin{array}{ccccc}R & 0 & \cdots & 0 \\ 0 & R & \cdots & 0 \\ \vdots & \vdots & \vdots & \vdots \\ 0 & 0 & \cdots & R\end{array}\right]\left[\begin{array}{c}\beta_{1} \\ \beta_{2} \\ \vdots \\ \beta_{N}\end{array}\right]=\left[\begin{array}{c}e_{1} \\ e_{2} \\ \vdots \\ e_{N}\end{array}\right]$. Each cell reports the $\chi^{2}$-statistic for testing the restriction as well as the p-value, reported in parentheses. The number of apartment types associated with each entry in the table is reported in Table 2. 


\section{Conclusion}

Most previous studies testing the present value relationship (PVR) in financial markets have strongly rejected the hypothesis of market efficiency. But these studies rely upon dividends set by firm managers. Other studies applying the PVR model to housing (making imputations of dividends from the rents of "comparable" dwellings) have similarly rejected the hypothesis of housing market efficiency. But these latter studies are typically based on evidence from North America, where housing and housing markets are quite heterogeneous and where detailed observations on rents and selling prices for the same dwellings are not available. In contrast, we have exploited here the unique features of the Korean housing market-where dwellings are homogeneous and observations on both market rents and selling prices are available for each unit. We test several important restrictions implied by the present value models using panels of prices and rents in Korean condominium submarkets. The results imply that we cannot reject the hypothesis of market efficiency for Korean condominium markets throughout the 1990s and early 2000s, for the period before or after the Asian Financial Crisis of 1998. Information on expected housing returns is reflected in the level of current rent as postulated by the present value model of asset pricing. Our results may also suggest that the conclusions of previous studies of housing market efficiency have been compromised by inadequate information on rents and values for dwellings.

\section{Appendix A: The Classification of Housing Submarkets}

Figure 1 in the text depicts the seven geographical submarkets in the Seoul Capital Region. The submarkets are rather distinct in terms of history, industrial composition, and housing market development. This appendix provides a more detailed description of each of these submarkets.

\section{Seoul Region 1: Central and Northwest Areas of Seoul}

This is the old center of the city. This area has served as the political, commercial, and cultural center of the nation, and has provided comfortable living environments for the nation's elites. Developed before the rising popularity of apartment living and universal auto ownership, the area could not accommodate to the life style changes of Koreans. It has thus lost well-to-do residents to districts south-of-theHan River since the mid-1970s. Today, the area still is the commercial and cultural center, but except for some large single family homes, residential units tend to accommodate middle and low income households.

\section{Seoul Region 2: Northeast Areas of Seoul}

This region consists of old industrial areas and suburban farm lands. As Seoul expanded, farm land was developed and turned into high-density apartment complexes in the 1980s and the early 1990s. Residents of this area tend to be middle and lower middle income households. 
Seoul Region 3: South-of-the-Han River

Developed since the mid-1970s, this area (called Kangnam) could accommodate to as rising car ownership and high density apartment living. As more upper middle class households moved into apartments in the Kangnam area, local public services such as education were upgraded, attracting more well-to-do families. The apartments in this area have shown higher rates of price appreciation than those in other areas. The area now boasts world class business facilities and opulent residential units, accommodating high income households.

\section{Seoul Region 4: Southwest and West of the Han River}

This region contains old industrial areas and the southern bank of the Han River. The river bank was turned into massive apartment complexes in the mid-1980. The old industrial part is being transformed into high-density residential complexes and high-tech research and industrial centers. Incoming residents tend to be middle and upper middle class households.

\section{Kyunggi Region 1}

This area stretches from the northern and eastern boundary of Seoul to areas close to the border with North Korea. Korean and American military forces are highly concentrated here. The northeast portion of the region provides inexpensive suburban residential units to low to low-middle income households. Smaller new developments around Ilsan, a new town developed in the early 1990s, provide comfortable living environments for mid to upper-middle income households.

\section{Kyunggi Region 2}

Located on transportation corridor between Seoul and other large cities to the south, the southeast portion of the submarket contains several old suburban cities. Some are industrial cities serving Seoul, and others have their own special character. For instance, Kwachon city has a large central government complex. To the southwest, this area contains Bundang, a new town developed in the late 1980s. Living environments are now considered as excellent and average house prices are higher. Residents are mostly middle and high income households. By the late 1990s, many smaller residential developments sprang up to the south of Bundang. These often lack modern infrastructure such as rail linkage to Seoul, and provide poor living environments.

\section{Inchon}

Inchon is the second largest port of the nation, and has attracted heavy industrial factories such as steel, machinery, and transportation equipment. The city was developed early, and it could not easily accommodate modern residential living arrangements. However, the opening of an international airport and the completion of a few massive land reclamation projects are expected to change the structure of the local economy and improve living environments. 


\section{Appendix B: Time Series Properties of Housing Prices Analyzed in the Text}

The observations on rents and condominium sales are not taken directly from actual transactions, rather from the observations reported by brokers and market participants. The shortcomings of non-transactions prices, such as appraisal-based prices, are well known. To evaluate the potential for the smoothing of reported prices, we investigate the autocorrelation of log price changes. We estimate

$\Delta \log \left(P_{i t}\right)=\beta_{0}+\sum_{k=1}^{4} \beta_{k} \Delta \log \left(P_{i, t-k}\right)+v_{i, t}$,

where $P_{i, t}$ indicates the price of condominium type $i$ at time $t$. If prices reported by brokers are slow to reflect market changes, then condominium prices should be predictable, at least in part. Equation (B.1) is estimated for each of the 864 types of apartments which have complete panels covering the whole sample period. Table B1 summarizes the results from the regressions estimated separately for each type. As indicated in the table, the vast majority of these series exhibit no predictable pattern in price changes over time. The average of sum of the coefficients of lagged changes is quite close to zero, and the null hypothesis that each of the lags is zero cannot be rejected for the more than 80 percent of the individual series. The average of the Durbin-Watson statistics also indicates that there are no predictable components in the error terms for the regressions. Thus, even though the prices and rents analyzed in the text are not obtained directly from actual transactions records, the observations do not appear to suffer from usual shortcomings of non-transaction based prices.

Table B1 Summary of regressions investigating the predictability of housing prices

\begin{tabular}{llcc}
\hline & & $1990 \mathrm{Q} 1 \sim 1997 \mathrm{Q} 3$ & $1999 \mathrm{Q} 1 \sim 2000 \mathrm{Q3}$ \\
Sum of coefficients & Min & -3.8061 & -2.1232 \\
on lagged changes & Max & 1.3413 & 1.0577 \\
& Average & -0.0160 & 0.0686 \\
Adjusted $\mathrm{R}^{2}$ & Min & -0.2158 & -0.1164 \\
& Max & 0.7720 & 0.4521 \\
F-statistics & Average & 0.0671 & 0.0373 \\
& Min & 0.0237 & 0.0358 \\
F-test & Max & 19.622 & 8.6314 \\
& Average & 1.7412 & 1.4923 \\
& Percentage of Rejections & $18.63 \%$ & $15.16 \%$ \\
DW & (in 864 separate & & \\
\hline
\end{tabular}

The table summarizes the results from 864 regressions, one for each housing type observed continuously during the period 1990-2002. Regressions are of the form:

$\Delta \log \left(P_{i t}\right)=\beta_{0}+\sum_{k=1}^{4} \beta_{k} \Delta \log \left(P_{i, t-k}\right)+v_{i, t}$. 


\section{References}

Ackert L, Smith B (1993) Stock price volatility, ordinary dividends, and other cash flows to shareholders. J Finance 48:1147-1160

Ambrose BW, Kim S (2003) Modeling the Korean Chonsei Lease Contract. Real Estate Econ 31:53-74

Campbell J, Shiller R (1987) Cointegration and tests of present value models. J Polit Econ 95:1062 1088

Campbell J, and Shiller R (1988) The dividend-price ratio and expectation of future dividends and discount factors. Rev Financ Stud 1:195-228

Chang Y, Song W (2003) Panel unit root tests in the presence of cross sectional dependency and heterogeneity. Working paper, University of Houston

Craine R (1993) Rational bubbles: a test. Journal of Economic Dynamics and Control 17: 829-846

Diba B, Grossman H (1988) Explosive rational bubbles in stock prices? Am Econ Rev 78:520-530

Gilles C, LeRoy S (1991) Econometric aspects of the variance-bounds tests: a survey. Rev Financ Stud 4:753-791

Hamilton J (1994) Time series analysis. Princeton, NJ: Princeton University Press

Hamilton J, Whiteman C (1985) The observable implications of self-fulfilling expectations. J. Monet Econ 16:353-373

Kim S (2000) The structural changes in Korean housing market and new housing finance policy. Housing Studies Review 8:247-268

Kleidon A (1986) Variance bound tests and stock price valuation models. J Polit Econ 94:953-1001

LeRoy S (1989) Efficient capital markets and martingales. J Econ Lit 27(4):1583-1621

Marsh T, Merton R (1986) Dividend variability and variance bounds tests for the rationality of stock market prices. Am Econ Rev 76(3):483-498

Meese R, Wallace N (1994) Testing the present value relation for housing prices: should I leave my house in San Francisco? J Urban Econ 35:245-266

Poterba J (1984) Tax subsidies to owner-occupied housing: an asset market approach. Q J Econ 99:729-745

Son J, Won YH, Moon CG (2003) Changing conditions and quality of housing. Soc Indic Res 62:211-237

White H (1980) A heteroskedasticity-consistent covariance matrix estimator and a direct test for heteroskedasticity. Econometrica 48:817-838 